\title{
TRUE BENEFITS \\ OF PEER REVIEW
}

THE BADGE SYSTEM - THE PREFERABLE ROUTINE FOR PEER REVIEW?

- Publishing libraries can together acknowledge action in scholarly communication

\section{TRADITIONALLY}
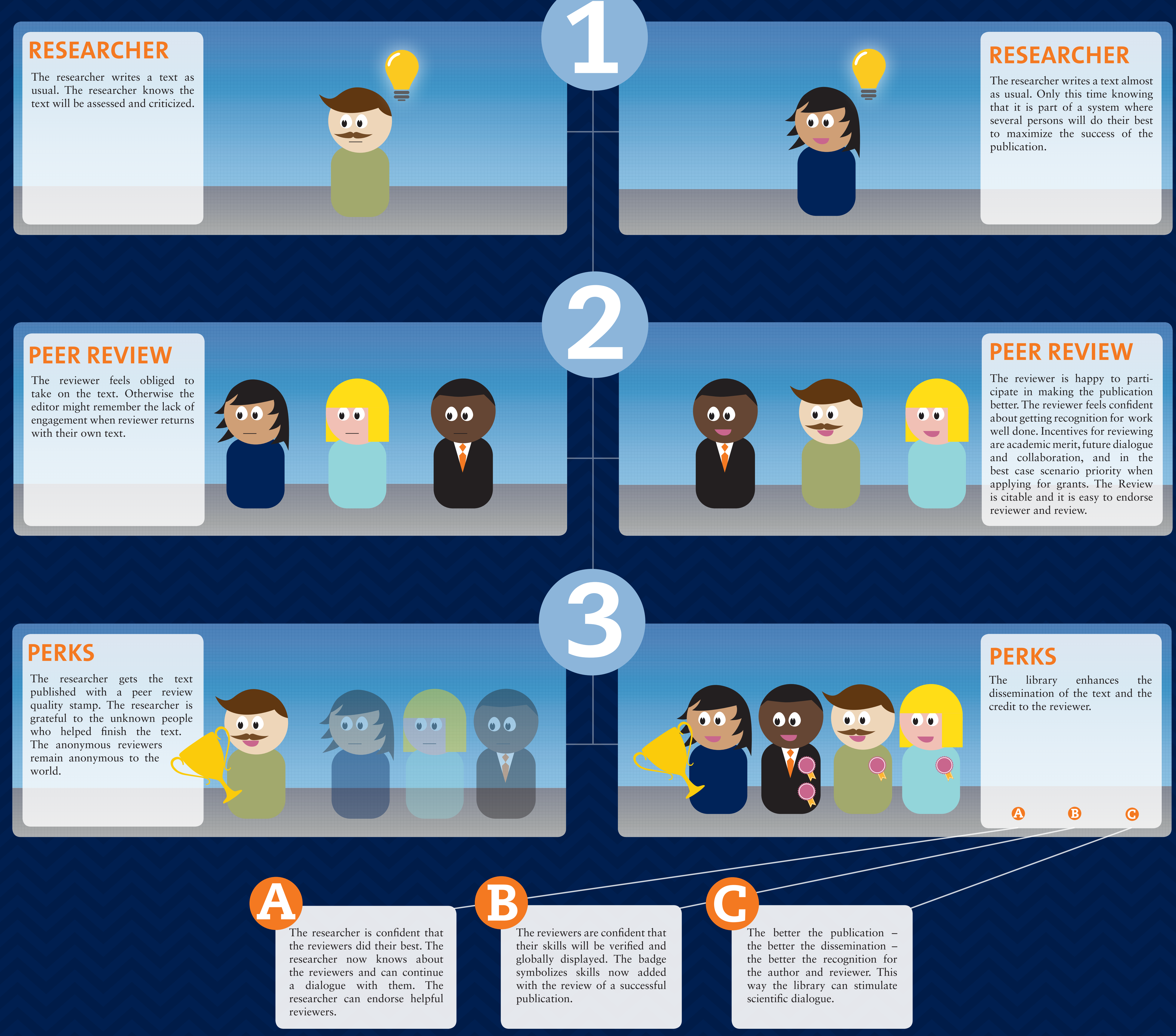